\title{
Notes by Jan Górnicki (Ber Oszer Weisbaum)
}

We are publishing the notes written by Jan Górnicki, in May 1945, shortly after the liberation of the camp in Germany where the author had been brought in the aftermath of the liquidation of the Warsaw ghetto and internment in other camps. Regarding the approach to these notes as a source document, the only changes being essential additions and footnotes. The notes are preceded by the author's biography, written by his son Jarosław.

Barbara Engelking

My father, Jan Górnicki, died on 16 December 2006.

He was the only child of Solomon Weisbaum (born in 1901) and Helena Weisbaum, née Okuń, from Białystok. The death certificate does not contain this information.

My father lived with his parents in Warsaw in the apartment of his grandfather - Israel Weisbaum, who rented it for 150 zlotys per month. Israel's wife, Zofia, known as Zysia, had a son called Herman from her first marriage and she had three more children with grandfather Israel: Frania, Salomea, and Szlamek, [also called] Szlojme or Solomon, who was later to become Jan's father.

Little information has survived about Jan's mother, Helena. She had two sisters, Genia and Sonia (Sznajdla). Genia lived at 53 Nowolipie Street, she had two children with her first husband: Henryk and Izaak; her second marriage to Rozenblum was childless.

Sonia married Abraham Librach and they had two children: Matylda and Leon. They went to France before the war.

The apartment of Jan's grandfather, Israel, had six or seven rooms, with about 24 people living there. The largest room was for Israel and Zysia. It was divided so that their daughter Sala (Salomea) could live there with her crippled daughter who died soon after.

In the second room lived the second daughter of Israel, Frania, with her husband Złotkiewicz and their daughter Fela.

In the third one - Jan's parents, Hela and Szlamek, with Jan himself.

In the fourth, fifth, sixth, and seventh - there were tenants, a total of fourteen people. 
Those tenants were very poor. Very little was collected in terms of rent, there was never any light in the common corridor. The apartment was paid for by the grandfather, but not always, because Jan remembered bailiffs. They would come to take the wardrobe, but they would leave it when it turned out that it was only a doorframe leading to the next room. And yet Jan remembered that a colleague from school came to visit him and his mother would always give him dinner because that boy never had any at home.

As a little boy Jan remembered that all windows were barred from the third floor up: because there were often suicides in those apartments. There were also some in his family. Jan's grandmother, mother of Helena, committed suicide before the war. Her father was a Russian soldier who had disappeared without a trace somewhere.

During the war, Jan's aunt Genia, his mother's sister, committed suicide after the loss of her husband and two sons.

It was Jan's grandfather, Israel, who supported the family. He had a small shop on the corner of Zamenhofa and Gęsia streets. He worked there with his daughter Sala; there were four tables where people could order something, breakfast, coffee, or cakes. It was one of Jan's most treasured memories, when he would visit his grandfather in the shop and he gave him scrambled eggs and 50 groszies for his mother to buy bread. He did not remember there being not enough food in the house, but the scrambled eggs remained as the memory of a full stomach, the warmth of his grandfather's shop and a sense of security.

At home the children were spoken to in Polish. The parents spoke Yiddish when they did not want the children to understand. Jan understood it, but he did not speak it, he did not want to. Everyone called him Bronek at home, although his birth certificate allegedly said Ber Oszer.

There was a mezuzah on the door at home, but it was out of respect for his grandfather Israel. But before the war, there were not even any candles on the Sabbath, so they did not light any. Jan did not remember any Sabbaths spent together. His father used to go to the synagogue on Yom Kippur.

Jan remembered that he was annoyed by the Jews with side locks living beside the same staircase. He saw them mechanically reciting the Torah, he saw "onion-and-garlic-smelling" teachers slap them on the hand with rulers when they made a mistake in recitation. "It's because of the likes of them that people don't like us. No wonder, they really are terrible," he remembered his reaction.

Jan's father worked part-time as an accountant; it was always difficult to manage in-between paydays. But books were a priority at home. Jan "devoured" Polish literature and he taught his children and then his grandchildren to love Sienkiewicz's trilogy.

He lived in the ghetto; even though there was no wall then, venturing beyond the Jewish district was not safe. The Saxon Park was the limit of the neutral zone. Once, when he went with a friend, Zygmunt Tenencwajg to another part of town, a boy scout came up to them and hit Zygmunt in the face. Jan did not look like 
a Jew so he was not struck. He told the story that incident many times. He was about ten or twelve years old at the time.

He remembered how afraid he was when he went to Jerozolimskie Avenue to collect his prize for collecting a full set of credits on some promotion for "Donald" chewing gum. He was twelve years old and scared after his past experience.

The next time he went outside the Jewish quarter was at the Independence Day parade, and Piłsudski was supposed to be there. The crowd became unruly so a policeman began to beat the Jews with a baton. Jan was also hit. It reminded him of a fire on Pawia Street when the police were happily striking the Jews while shouting "Move along! Move along!"

Jan went to a Polish school in the ghetto. That meant that lessons were taught in Polish and that Sunday was a free day. He studied French for a year and because of the excellent teacher, who spoke to them only in French, he was able to converse in that language for the rest of his life. He mentioned a good teacher of mathematics, although he also remembered how that teacher called him an onion-stinking Jew. Despite the humiliation Jan was keen to learn and he was very upset when he could not go to school for a year because they did not have the money. He treated it as a personal failure, especially significant since the fault was not his. Reading his memoirs, I think he suffered a trauma caused by his father's ineptitude. Especially since he was known to lose money playing cards.

Despite the break in his education, Jan managed to pass the so-called mała matura [small matriculation - secondary school graduation exam] before the war at the Spójnia school; I think it was at 29 Długa Street.

There was the traditional bar mitzvah, for which he was prepared by his grandfather. The best memories of his childhood were those involving his grandfather. He took him to the cinema, he read him books, and he told him interesting stories. He even taught him the Hebrew text, which Jan then recited during the ceremony.

But Jan had told his grandfather that did not believe in God by then.

One of the tenants in the apartment, Fleker, was a bookbinder and a communist. He gave some papers to them (Jan and his colleagues from the Union of Polish Communist Youth ${ }^{1}$ ). They were excited about this, because it was forbidden literature. The father of his friend, Benek Tykociński, arranged a job in Sosnowiec for Jan's father just before the war, in a hat shop. It was a breakthrough - Jan got a new bike. The Tykocińskis helped them in yet another way: they took holidays abroad, while Jan's family took care of their house in Falenica. For Jan it was a great vacation: a lot of light in the house, a lot of books and a bicycle. Because of that bicycle Jan had a real adventure - he met another cyclist while cycling and found out that he was a Pole, who was neither a Catholic, nor an anti-Semite - a Protestant. It was a real, joyful surprise.

${ }^{1}$ Actual name: Young Communist League of Poland (Komunistyczny Zwiq̨zek Młodzieży Polskiej, KZMP). 
The war found them in Falenica. Gendarmes confiscated the bicycle of the caretaker, a Pole. After their departure, the caretaker requisitioned Jan's bike...

After returning to Warsaw, at first Jan worked for the Germans at the socalled work details. The next period of his more or less steady work is described in the published memoir.

However, the episode of the meeting with his grandfather is not there. For some time, Jan lived with his mother at 53 Nowolipie Street (after the suicide of his aunt Genia, his mother's sister. Two of her sons had been killed earlier, and after the death of her second husband, Rozenblum, she could not take it anymore, so she vacated the apartment...). Those were happy days; he had his own room, light, and a balcony overlooking the courtyard where a tree grew. In the ghetto, it was the ultimate dream. But resettlement and deportations started soon after and it was not possible to move around the ghetto during the day. During one of his nightly excursions, Jan went to the old apartment of his grandfather. $\mathrm{He}$ found him alone in bed. He was so starved that he could not move on his own. He had been lying there for several days. Other tenants of the apartment had been deported or killed by the Germans. The Germans left grandfather alone because, as they said, it would be a waste of a bullet. My father also left him - he told me that it was so obvious that he could not take his grandfather with him that they did not even talk about it.

Father's memoir ends with improved conditions when he started smuggling food into the ghetto. But this "idyll" was short-lived. Captured on 22 November 1942 on the "Aryan" side carrying "Aryan" documents, he was taken to Pawiak. His friend Jarząbek was shot while trying to escape.

The blue diary contains a poignant description of the first day at Pawiak.

And another episode omitted in the description. Medical examination. He stood naked in front of a doctor, who looked at him and saw that he was circumcised. He said in amazement: "Oh," and wrote something in the documents.

From that moment on father was waiting for the "firing squad," as he said, until one night he was transported in a group of prisoners to the camp in Pustków near Dębica.

It was a camp known as a "finishing place," but my father said that for him the difference was that they received something to eat twice a day. So it was better.

He said that only two or three people in the barrack could leave a piece of bread for the following morning, in order to have the strength to work for over twelve hours a day.

One time he could not ignore that his only friend in the camp, Władek Gostyński, was looking at his slice of bread. Gostyński had earlier exchanged his piece for cigarettes. Father shared his bread with him, but I think this episode left him disgusted with all addictions. Władek was the only one who knew that father was a Jew (after the war, father found him, brought him to Poland, and gave him a job - again, that is another story). In the camp, Jan had to hide from 
both the Germans and the Poles. It was not easy at the weekly "szwanc-parades," or communal baths in the shower.

He remembered what happened at Pawiak. He learned a special walk to hide his circumcision. He still had that bizarre walk in the shower when I went with him to the pool as a kid...

In Pustków, there was a separate camp for Jews and Gypsies. Jan spoke with an older colleague, well-read, from a family with National Democratic traditions. "In my house there were no portraits of Piłsudski," he would boast. And on Sunday, looking at the Jewish camp, Staszek Szuro said that he was glad that Hitler at least dealt with the Jews (after the war, father testified at a trial where Szuro was sentenced to death. He was not executed and when democracy was reinstated in Poland, the man, an active participant in the struggle for freedom in the 1940s, was rehabilitated. But during the trial father testified against him. Though later in the 1970s, or maybe even later, he wrote to him. But there was no reply).

"Come on," Jan said. "Just look at us, we are here just as they are and we do not know whether we are going to survive. A common fate awaits us under the Germans. How are they worse?" "You are defending the Jews? There are only three types of people that defend the Jews: Esterka - a Jew lover, Shabbes goy - the one that works for the Jews, or you are a Jew yourself." Maybe it was supposed to be a joke...?

It was there that father saw Count Wojciech Dzieduszycki. He was a kapo by virtue of his position. But when they told him to beat a prisoner, he refused, even though he knew that he would be beaten himself. He got 25 lashes, and some people never got up after that. Jan remembered some kapo who could beat prisoners to death.

After two years in Pustków they were moved to Sachsenhausen. It was a much milder camp, but Jan had already been exhausted by work and typhus in Pustków. He survived because of the Communists he met in the camp, who somehow trusted him. They gave him a job in the kitchen. He "recovered" on potato peelings...

He was liberated from the camp in Oranienburg on 25 April 1945 by the $1^{\text {st }}$ Byelorussian Red Army. He weighed about 40 kilograms at that time and walked like an automaton. In the camp, such "numb" prisoners who were about to die were called "muslims."

Father returned to Poland with the Anti-Aircraft Division.

In May 1945, when the army made a halt in a small town near Berlin, he recorded his recollections from the ghetto published herein. After returning to Poland he reported to the local authorities in Kraków with a certificate from the army. He was offered a job at the Security Office (Urzq̨d Bezpieczeństwa, UB), but he still wanted to learn; he became involved in various initiatives: only three months after the liberation he was made the chairman of the Provincial Board of the Union of Fighting Youth (Związek Walki Młodych, ZWM) in Kraków. 
For the sake of a better future for young people similar to him, those from "the starving cities and burned villages," and also for the children he had not yet had himself, he established youth organizations, he gave numerous lectures, and he taught others and himself how to help to build (as he believed) for the common good.

He was a non-believer. He saw the Catholic religion in Poland as the main cause of inequality and illiteracy among the peasants, as such people are easier to manipulate. He regarded ignorance as the cause of racial hatred and dislike of the new system and the agricultural reform. After what he had experienced, he saw nothing but hypocrisy in the church.

In 1947 he was transferred to Warsaw, where he worked in the Executive Board of the Union of Fighting Youth, and then the Executive Board of the Union of Working Youth ${ }^{2}$. He became involved in developing the scouting movement. He still "converted" and educated people, he was studying himself, too. He graduated from the Diplomatic and Consular Faculty of the Academy of Political Science.

He was upset about the year 1956, but he saw it rather as the end of "errors and distortions." He believed that if the party errs, one must err along with the party and exercise a degree of individualism. He saw no other way. Even when his comrades and friends were leaving because the thaw entailed "cleansing" the army and the party of Jews; he never considered leaving Poland. The Jewish State in Palestine was alien to him. He was born in Poland and his home was here. None of his family had survived but he had his own family now: his wife and two children for whom he felt responsible.

In 1967 he was transferred from the Provincial Committee of the Polish United Worker's Party (Komitet Wojewódzki Polskiej Zjednoczonej Partii Robotniczej, KW PZPR) to the Metropolitan National Council (Stołeczna Rada Narodowa), where he worked until retirement.

The anti-Semitic campaign in 1968 made father feel threatened again. He avoided direct confrontation, subconsciously feeling like a hunted animal that needs to hide. He still believed that it was only a momentary eclipse, and that it would improve again. But it did not, and - "for health reasons" - he was sent to a post in Yugoslavia in 1971.

At the time, for employees of the power system, it was an exile rather than a godsend.

It was only in the 1970s, there in Yugoslavia, that he believed that the Katyn massacre was the work of Stalin. It was there that he read Solzhenitsyn's Gulag Archipelago for the first time. He had less and less enthusiasm, and more and more doubts. But he still could not see any other way. He has, as he always had, the main objective: only under the nuclear umbrella provided by the Soviet Un-

${ }^{2}$ Actual name: Union of Polish Youth (Zwiq̨zek Młodzieży Polskiej, ZMP). 
ion can we make life better, more equitable, and reduce inequality. He had an especial need of that "umbrella."

Having returned from Yugoslavia, he was pushed onto the "back burner" until his retirement in 1982, he worked at the Institute of Fundamental Problems of Marxism and Leninism of the Central Committee of the Polish United Workers' Party. Just before martial law was introduced, he felt that conflict was inevitable. He had worked in the structures of the communist regime from the beginning and he understood what might happen. After the period of martial law, he continued to do volunteer work and he worked with the PZPR organizations in various institutions.

After 1989 there were many changes. He accepted it. He talked about the past more and more.

When, after graduating from high school, I wondered what to do in life, Father told me that his work always gave him the most satisfaction when he could help someone.

The idea to help the weak, learned at home, accompanied him throughout his life.

He raised us to believe that being a decent man is important in life, that it is important to be honest in what one does, and one's objective should be to help the weak. And it is possible, he repeated after Tadeusz Kotarbiński, if you love someone.

And so for sixty years he had his Heluśka, one of the first women communists after the war in Podhale, sentenced by the Underground, without whose love (he kept saying) he would have nothing.

He chose to be cremated. In this symbolic way, as he stressed, he wanted to join his family. He chose that for himself. His family in Treblinka and Auschwitz had not been given any such choice. 


\section{Jan Górnicki (Ber Oszer Weisbaum)}

\section{Notes}

22 July 1942. For the past several days the whole Warsaw ghetto lives in nervous excitement. Some tension is in the air and everyone is waiting for something. For several days, day and night a couple of small elegant cars have been cruising around in the neighborhood. Cars of death. They stop in front of marked houses. A group of smartly dressed Gestapo officers, usually accompanied by a civilian, get out and, with the paper of death at the ready, enter the gate. With the fear and curiosity that overcomes indifference and dementia, people watch it from a distance. They do not have to wait long. In the house, into which they disappeared, a gunshot is heard. Calmly, as if nothing happened, they return, the car doors slam, the engine is started, and they stop again at another house marked on the death list. And were someone curious enough to peek into the house, he would find a dead body with a shattered skull in the yard or on the stairs, usually with terror written all over his face. Mostly, people who were taken out of their homes in the ghetto at the time knew what awaited them. It was usually teachers who died this way, people with some influence in the neighborhood, or those who had it once. People, who worked in charity organizations, and those who were accused by some vile informant of involvement in the Underground or political activity, were also in danger. In the second half of July many such cars were cruising around in the ghetto, taking a bloody death toll. One can imagine how the heart palpitations of the householder, by which a private taxi with an "SD" number plate stopped. Withholding breath, waiting in terrible fear and, finally, what a relief. They had come for the neighbor this time. So it is not today. And the door is not open, and no one goes to see the dead, because it that is just that - a dead body. They all look alike, and there is no lack of them in the street, both those shot, and those who have died of hunger.

22 July. It is clear that something is stirring. The realization is immediately associated with all sorts of rumors circulating in the district about deportation and expulsion of large numbers of Jews. Only the poorest had nothing to fear. Often, one would meet beggars and people of some unspecified profession, whose occupation was roaming the streets all day long. They were seeking to earn something, a piece of bread, and they did not care how they obtained it. By stealing, robbing, cheating, begging or working for it. But in the Jewish quarter in Warsaw, even enterprising people, even those ready for everything, who did not care anymore, found food difficult to obtain. Constantly hungry, they were so desperate that they were willing to pillage and even murder, they were only waiting for an opportunity, for someone braver who would start it. They did 
not look whether their victim was rich, or a poor man like themselves, trying to sell his meager merchandise, and whose entire existence and trade were destroyed, who, even if defending himself with all his might when attacked, has no strength left in him anymore. The hungry horde of gaunt shabby men is fighting for a bunch of carrots from his handbarrow. The owner is left with his empty barrow, weeping.

Often, the last resort disappears like that and there is nothing left but to go to the street and look for something in the way of those men by whom he had just been robbed. It was inevitable anyway, he had sold everything at home, the war is not over and the Germans are winning.

And there is the constant hunger, and even worse - hungry children at home, children who do not even ask for food anymore, because those three-year-old people have realized by now that there is nothing to eat. If only one could die and not see the hungry eyes of emaciated children. Your own children that you cannot feed. Even if you were to beat your head against a wall. Children whose dream it is to buy a lorry load of bread after the war and eat, eat to their heart's content at last. Strange are these children of vegetating and exhausted merchants, porters, or laborers, or other impoverished ghetto prisoners. Children who do not know how to laugh out loud or play. Children who move silently as shadows, with their hungry look, the most terrible look there is, search for something to eat. One must not eat in their presence. Every bite is followed by hungry, greedy eyes. Children whose only interest is food, who talk of an event as miraculous as eating a piece of beetroot. Yes, I saw thousands of such children. And unfortunately, even though I have always thought I am fairly sensitive and that I can understand someone else's misfortune and sympathize with them, I have realized that actually I am numb, that I simply do not care. More than once I have seen homeless children begging in the street in rags, with dirty yellow bodies and protruding bones visible, with a plaintive voice wailing a song softly, and another one crying. Dirty, grimy, with stench smelt from a distance, with huge lice crawling all over their skin, these children had strange faces. The faces of adults. One could see a stigma of experiences so horrible that it was clear that they would never smile again. In fact, I had never seen these children laughing. Sometimes when I saw their little corpses in the morning, still lying on the concrete where their lives had ended without ever having known anything good, I tried in vain to arouse at least a glimmer of regret. But I have become a strange man. My senses and my soul have become covered with a thick coat. I also have only one purpose, how to earn a piece of bread for myself and for the mother. There was the lowest caste of poverty. There were beggars lying along almost every street on both sides, every few paces. A large variety of groups, families dressed in rags, children by themselves, old women, old men, young skeletons, and cripples of all kinds. They all had several things in common. They were wearing the worst rags imaginable, they were hungry, and they all looked alike. Masks instead of faces, gaunt, sunken eyes, the yellowish or sallow com- 
plexion of the soon-to-die. Masks with dull eyes and identical grimaces. Some loudly begged for mercy, while others again were silent all day. Many had photos of better times. You could see a decently dressed man or a happy family photo, with the whole family happy and smiling for the camera. And then comparison, disgust, and disbelief. After all, one must not look at this monster, this scrap of something that once was human and now lays claim to life, and compare him to a normal man. And there was the feeling that wished him a speedy death that would always be better than this terrible and spasmodic grasping for the remnants of what is still called life. It was the only pity I could muster. And how often did thoughts go through my head that the next step after selling everything in the house is likely to be the stage under the wall. Among the beggars there are old friends who have had the same rags since the winter of 1941/1942. With bare skin showing through, usually barefoot in the freezing snow, slowly, step by step, they walked through the streets, begging, singing rhythmically a wailing melody, asking for bread. Now they too are dying, among the ever-growing crowd of beggars. Many of them fall. It is a normal scene in the street - a ragged man, with the ever-present numb grimace of a skeleton, who walks slowly, dragging his feet. At one point he falls down, he shudders and is convulsed for a moment, and then the man is gone. The streets in the district are constantly crowded. To go down the street meant to follow the one in front of you, it was difficult to overtake anyone. And those people would pass a corpse lying on the pavement as casually as if it were a piece of rag. Among the thousands of people who walked past him and trampled him, it was difficult to find a compassionate passer-by who would drag the dead body to the side. And if one was found, he also had to wait a long time and ask others to help him remove the corpse. Finally, someone reluctantly stopped. The corpse is tossed hard and impatiently against the wall, and sometimes, although it is completely pointless, his head is covered with paper with a brick on top to hold it in place. It is clear that people have become indifferent, because only at the beginning was a dead body on the sidewalk not an everyday occurrence. Recently, before the deportation, streets were full of corpses covered and uncovered, lying under the walls between the living dead, who saw their own future and the best and last stage of their suffering immediately before them.

There were mostly young boys to be seen, but it was hard to tell that they were indeed young. Ragged, their faces turned into battered masks with slit cheeks and foreheads, filthy, covered with blood dried into scabs. They were the so-called hapers. Whoever was in the Warsaw ghetto, knows what it means. It comes from the Hebrew word "to catch, to pull." They usually hovered on the sidewalk against the wall, watching passers-by intently. There were throngs of them in front of grocery stores, pastry shops, or bars. As soon as a haper saw someone with a packet leaving the shop, or walking down the street, he would not leave the victim. He would circle around until he found the right moment. He would lunge with all the strength he had left, and then the living skeleton 
would attempt to escape with the grabbed package. But he knows perfectly well that he will not succeed. Running, he is trying to eat as much as he can of what he has taken. Clumsily shaking hands shove as much as they can into the mouth. After a few steps, he is overtaken and captured. Five or six people try to get his trophy out of his thin, dirty fingers. Everyone beats him and then they kick him when he's on the ground. What he has not eaten eat is crushed anyway, mixed with mud, squashed under the haper, who, weeping, beaten within an inch of his life, devours the remains of his loot. It is probably his penultimate meal. When they beat him next time, he shall probably not get up. Slowly, swaying, he is trying to get up; after several attempts he manages to kneel and rise with difficulty. People pass him indifferently. The chance passers-by who intervened and beat him are gone. There is only a woman or a child standing by, also crying because the bread that he took was bought with the money from selling the last piece of linen, or the weekly earnings of a father or brother working at the German detail, which can buy two loaves of bread. The haper rises, and then falls down again, eventually he manages to stand. Another one kneels beside him, looking not much different, only not as bloodied. This one is less courageous. He just collects the crushed, trampled crumbs from the ground. He picks each one carefully. He cleared them all. He looks one more time and picks one more crumb from the mud. Then he gets up with difficulty and slowly walks away. He disappears into the crowd, just as the haper has disappeared, and the girl. After that, no one remembers anything, no passer-by thinks about it. A tragedy, one of many played out on a stage that is the street. One of many seen at every turn, until one is you completely unmoved. An excellent piece of material for a writer. So many impressions, insights, and a great study for anyone seeking the human soul. Even when sometimes one recogniszs a former friend in this remnants of a man, it still leaves one unaffected. It is not an unknown stranger and yet you cannot see any difference. This is the man whom I saw laughing and talking, and he could somehow express his feelings. This is a man who had a family, he loved and was loved. He thought, he learned. And now he has turned into a living corpse with one only thought left, to fill his stomach, to maintain a feeble spark of life.

Beggars in grocery shops bought the three decagrams of bread for 50 groszies. Day and night, the streets were filled with pretty young girls.

They wanted to save themselves at all costs. They wanted to ward off the threat of poverty, so they went to the street. One could often see those that were supposed to be standing provocatively, but all that one saw were the eyes of a young handsome girl fixed on the ground, her whole stance communicating nothing but shame. I met schoolmates from school among them, with whom I once sat at the same desk. Sometimes, they were girls brought up to blush at a lewd joke. Now, they wanted to live, not die of starvation at home or under a wall. But even that did not save them. I had an excellent opportunity to observe the street. I had a rickshaw. A rickshaw was the most common means of transport in the ghetto. It was a bicycle barrow, like ones used before the war. 
Only instead of a box at the front, it had a padded bench on which people sat and I drove them. It was driven by the man pedalling on the seat behind the passenger. At the beginning, to have a rickshaw was of one of the best businesses in the ghetto. In the early days when it was still a rarity in the city, it yielded an income sufficient to support two or three people. The only problem was that it was very expensive to buy and not everyone could afford such a profession. I sold almost everything I had left at home and invested in it as a last resort. Before that I had worked in a German labor detail. 3.20 per day, the price of a quarter of a loaf of black bread. The shift started at five in the morning and finished in the evening. Within a year of work at the detail I lost over a dozen kilograms of weight.

I was weakened and emaciated because of poor nutrition to the point that my friends who had not seen a long time could not recognize me. My legs began to swell, and it always starts with legs. The memory of human trunks, horribly swollen from hunger, begging alongside dying human skeletons came to my mind. So, after long consideration and sometimes sleepless nights, I decided to hazard all on one card. I bought a rickshaw together with a friend. I was riding it for a half-day, and so was he. At first, we enjoyed a period of relative prosperity. In order to make ends meet and have enough brown bread to eat, I no longer needed to sell any things from home. But then again, everything went downhill. There were thousands like me and they did much the same thing. Every day there were more rickshaws on the market, and fewer passengers, rates become cheaper and often times we had to wait for hours. I was making half a living then but I was a well to-do anyway because most of the district lived practically on air, and I at least had some basis for existence. And during those hours without passengers I watched the life in the ghetto. And such tragedies were played out in front of my eyes that certainly nobody in the world has ever described. I remember a comical situation, but I clearly remember that no one laughed watching it, no one even wanted to laugh, and if people were not so numb many would perhaps have cried. Someone was carrying marmalade on a handbarrow. A tram caught on the barrow, the bucket fell and shattered. It was a cloudy March day. Wet snow was falling, turning immediately into mud in contact with the ground. The mud was trampled by pedestrians and vehicles on the road. And immediately a cluster of vagabonds with spoons and cans or pots began to gather, coming from all directions at once. The marmalade was immediately mixed into the mud down by their feet. Some were already lying on the ground, eating with spoons or hands, others, more provident, loaded it into pots. They were fighting in silence. One pushed away another, struggling, and yet their faces never lost their tragic expression. They faces betrayed neither thought nor emotion. The frozen mask did not express any outrage, any concern about the fight. It was their customary expression with sunken eyes and lower lip hanging in a vague grimace.

The marmalade with mud is already cleared. They rise slowly from the ground still licking their fingers; some of them even pick something from 
the ground. Everyone thoroughly cleans himself with a spoon or finger, and licks. And then one of them picks marmalade or mud from another's back with a spoon, and scrapes himself, and licks his lips. This fact requires no comments.

Riding my rickshaw I also came into contact with the rich of the ghetto. Most of them were people running some shadowy business with the Germans. Gestapo officers or smugglers - suppliers of goods to the other side and recipients. The war was good for them, they knew how to live. From one bar to the next, paying huge bills, from one rickshaw to another. Smartly dressed, squandering money, they flaunted their extravagance in front of the crowd. They were our best clients. Sometimes the payment for the ride exceeded my average two-day earnings. One had to be lucky to catch such a passenger. They filled bars, restaurants, and pastry shops. They were also indifferent to poverty, but often they would throw high value bank notes to the poor for show. And this is why most prosperous establishments in the ghetto were bars, pastry shops, and - with such high death rate - funeral parlors. Like mushrooms after rain, old haberdashery and industrial goods shops with no merchandise were turning into pastry shops, bars, or new branches of funeral undertakers.

Recently I have been having a lot of problems with my rickshaw. It kept breaking because it was damaged by car from Pawiak. SS cars drove into rickshaws deliberately, destroying them and injuring passengers. This also happened to me.

And it was those beggars from the ghetto that were neither afraid of taxis of death, nor displacement, nor the Germans, nor anyone else. "What else can they do to us, it cannot become any worse than it is. They shall not take anything from us because we no longer have anything."

22 July, after terrorizing the population of the district with continued shooting and killings, announcements were posted which read: As of today, deportation of the Jews from Warsaw starts. Direction: east. There, they will be placed in residential barracks and they will work in good conditions. It is permitted to bring fifteen kilograms of luggage. Excluded from the deportation are those employed in workshops working for the military and their immediate family that is wife and children. Signed by Fischer et al. ${ }^{3}$

${ }^{3}$ The regulation on deportation was posted on the walls of the Warsaw Ghetto on 22 July 1942; it was signed by the Jewish Council. It was dictated to the Judenrat by the Germans, and read, "The Judenrat is informed of the following:

All Jewish persons living in Warsaw, regardless of age and sex, shall be resettled in the East.

The following are excluded from the resettlement:

All Jewish persons employed by German Authorities or enterprises, and who can show proof of this fact.

All Jewish persons who are members or employees of the Judenrat (on the day of the publication of this regulation).

All Jewish persons who are employed by a Reich-German company and can show proof of the fact. 


\section{2}

The excitement subsided. Everyone knew what was going on. And what began that day, I can never write of chronologically. It was a horrible nightmare. A terrible three months and only those parts, those recurrent scenes, are so deeply etched in my memory that I shall never erase them from it.

First of all, a stampede began to all workshops. Everyone tried to obtain a certificate stating he was employed in a facility working for the military. The Jewish police began to gather beggars and shabby men from the streets on wagons and horse omnibuses. They did not defend themselves nor try to escape. Often, tightly packed wagons were roaming the city. The worst paupers were taken to the cemetery, where they were shot and not even buried. The quota was six thousand people a day. Then the operation was performed by SS troops, Ukrainians, and Latvians. Together with the Jewish police, they cleansed and cleared the ghetto of beggars. After that, problems started with delivering the quota of people - almost everyone had some sort of certificate for themselves and their families. The rich had certificates made for a lot of money and they were confident. Those who did not have a sewing machine to give to the workshop and get a beochciniung [Bescheinigung], or had not taken the money to buy it, they were also well hidden. The streets were full of people who felt fine and were not afraid of deportation. And it was these people who were the first to buy documents, the richest, that became the first victims. They began to take anyone off the street, regardless of papers and only very rarely were people left or ever returned. Whoever was taken usually never came back. And only after several weeks did people begin to talk, at first quietly and then openly, that those who were taken went to their deaths. Because the people who went had their fortunes with them, and weeks passed it seemed sinister that there was no news from them. At first, when I heard someone say that it was deportation to death, I would yell at him, and that was the general mood. Nobody would even admit the thought that the Germans would dare to do such a thing. After all, it is a historic responsibility to destroy a nation. It had to be deportation to work, but after a while the sad certainty began to dawn on everyone that we were condemned to death.

All Jews capable of work who have up to now not been brought into the labor process are to be taken to the barracks in the Jewish quarter.

All Jewish persons who are employed staff of the Jewish hospitals. This applies also to the members of the Jewish Disinfection Team.

All Jewish persons who belong to the Jewish Police (Juedischer Ordnungsdienst).

All Jewish persons who are first-degree relatives of the person listed under a) through f). Such relatives are exclusively wives and children.

All Jewish persons who are hospitalized in one of the Jewish hospitals on the first day of the resettlement and are not fit to be discharged. Fitness for the discharge will be decided by a doctor to be appointed by the Judenrat.

Every Jew being resettled may take 15 kgs. of his property as baggage. All valuables such as gold, jewelry, money, etc., may be taken. Food is to be taken for three days.

The resettlement will begin at 11:00 o'clock on 22 July 1942." 
The streets were empty. All traffic and trade stopped. There was no price for food and there was no food. Sometimes there was someone, who still thought of trading. For a loaf of bread, who knows where obtained, people paid any price. People were fighting for bread. Then came the second announcement that whoever volunteers to go would receive two kilograms of bread and one kilogram of marmalade. ${ }^{4}$ A clever trick. People, in order to put an end to it and finally eat their fill once, volunteered in masses.

For the first two months I was riding the rickshaw. I do not remember exactly what came after what. I remember countless wanderings with bundles around the city. Wherever we moved in, we had to flee from. There was a deadline to leave the district. After the set time there was a lock-out, that is the army checked if there was anyone left. Those found were shot on the spot. Aside from that, every day the army with the Jewish Order Service locked houses with people. An order to come down into the yard. Selection downstairs. Papers invalid. Old men, women and children to the side. The rest stays. There is no family, no father, mother, sister, brother, child. Horrible crying and screaming. Voluntary rejection of the exempt group and choice of death. Assuredly, a young mother will not leave her little son. At first I was even moved by that, but soon I became used to it. I saw myself how soldiers were checking emptied apartments.

Doors wrecked with rifle butts. Everything broken, destroyed. In the courtyard, shots from the apartments were heard. So perished, those who had the courage to hide. I saw myself as an upstairs window opened and a struggling woman or a child was pushed out. You can hear the groans of the broken torso on the concrete and it leaves you unaffected. It would seem that one does not have a heart anymore. I managed to protect my mother somehow. I drove her from street to street, where I sensed that there would be no lock-downs. Finally, through a friend, a brother of the head of a large workshop, I reached the workshop with my mother. And it was in the last month of deportation. I rode my rickshaw for the first months and I watched the deportation from my seat. Jewish policemen and we, the rickshaw drivers, had immunity almost to the end.

I had the opportunity to observe everything. The streets of the ghetto were hunting grounds and people - the hunted animals. I saw people murdered in the streets. And all left me unaffected. After that, it was pointless to go into the city. I was in hiding with my mother in a shed. I never wanted to leave her then. The worst was the fear that I would not find my mother when I returned home. Then I said to myself, what will be will be, and I left the rickshaw by some house; after

${ }^{4}$ On 29 July 1942 posters were pasted all over the ghetto, signed by the "Head of the Order Service," announcing as follows, "I am hereby announcing to all persons subject to resettlement according to the instruction of the authorities, that whoever voluntarily reports for on 29, 30, and 31 July of this year, will receive three kilograms of bread and one kilogram of marmalade. The place of assembly and distribution of food - Stawki Square at the corner of Dzika Street." 


\section{$514 \quad$ Materials}

that I stayed close to my mother. Mother was ill during the war; she had a liver and kidney condition. It was particularly difficult during the deportation. She suffered terrible pain during an attack. She was biting her lips and tore sheets, but she hardly made a sound so as not to worry me. But I suffered doubly, firstly because I was unable to do anything to help her, and secondly that I loved her more than anything in the world. I was an only child. Throughout the war I worked and took care of my mother as best I could. I received in return such great evidence of love and caring from her that it was for the only ray of light that shone through my many years of sorrow, sufferings and anxieties. I was so treated at home by my mother and surrounded by such an atmosphere when I came back home that I always immediately forgot about failures and daily torment. I called a doctor friend. He gave her an injection for a temporary relief from pain and said that she needed a good diet, butter, eggs, meat, white bread, and - above all else - peace and no concerns. I heard the prescription with incredulity. I spent sleepless nights thinking about what to do. I kept thinking about committing suicide together or voluntarily reporting to the deportation point at umszlakplac. I sold the last new suit, saved for the worst or better times, for 200 zlotys. Few Aryans came to the ghetto to do some work administration work, and they were the only buyers. They were inundated with merchandise. The most expensive things were exchanged for a piece of bread. One knew what to expect, and did not regret anything. Of those 200 zlotys I spent 120 zlotys a loaf of bread. What we were eating aside from that for weeks, I do not remember. I remember that I almost could not walk out of hunger, nor get up. I was dragging my legs. I will not even mention my mother. My heart was breaking with pain as I looked at this most beloved woman, once corpulent and large, and now almost skeletal. She was 40 years old and completely grey, almost white. And before the war, she had beautiful raven hair.

In the final month, the Jews were only allowed to live in three workshops and adjacent streets. They were at Prosta Street, by the Merchant Collective building - Toebens' workshop. 42 Nowolipie Street with the section from Karmelicka Street up to Smocza Street. Szulc's workshop, Świętojerska Street from Bonifraterska Street to Wałowa Street, with the brush-makers workshop at number 32. The Jewish Community on Zamenhofa Street from Pawia Street up to Gęsia Street. Empty houses were systematically checked and the remaining hiding people were dragged out, and half-dead from starvation, either killed or deported. The quota was still 6,000, but it was even more difficult to get people - so the lock-downs and operations were getting stricter and harsher. During the deportation, on the streets and in the houses, the unruly soldiery murdered about 150 thousand people ${ }^{5}$. Drunk, they murdered, raped, and robbed, undisturbed. Eve-

${ }^{5}$ During the deportation operation the Germans deported over 300 thousand people from the Warsaw ghetto to Treblinka, including 10,300 who died or were killed in the ghetto, 11,580 who were deported to Dulag, and about eight thousand who fled to the "Aryan" side. 
ryone still alive fled to the workshops, so lock-downs of workshops began. I was with the brush-makers. The first lock-down was done in such a way that those who were registered were given tin numbers. Then the Jewish police captured those without the tin plaques, who had taken refuge there, sleeping in courtyards or with relatives. Then they gathered everyone, about 2,000 for certain. They set the people in rows in the large square and checked tin plaques on their chest ${ }^{6}$. Elegant officers, with whips, organized the operation and beat those people captured in the crowd without tin plaques. Two thousand people went to the umszlakplac. For five hours we stood on the square in fear, knowing a decisive moment was approaching. Because they pulled the elderly, the drained, the emaciated, it passed. My mother's reaction was a liver attack again. So I am once again going through a horrible time. Even in my mind's eye, I do not want to look into the future, if my mother does not survive another attack. I did not allow myself such a thought because I felt that I was going mad. I felt pain in my heart, which ached. Then the number of those meant to stay with us in the workshop was reduced to eight thousand. The lock-down, anxiously anticipated for several days, began. An SS unit marched into the yard at Świętojerska Street. They started us to herd us with whips and kicking to the yard. And then for the first time tears came to my eyes. My mother did not manage to dodge and she was hit with a whip in the face. Immediately, a bloody welt appeared and the lips swelled up in that face, tired, sick, and yet so dear to me. This I will never forget as long as I live. Tears swallowed in pain and a welt on the face hurt me more than anything else in my life. I was later often tortured and tormented, but it was like a game compared to what I felt then. And the crowd swallowed us up. We ran down the stairs to the bottom [because of] the whips and there we were included in the vast line of the death. Trembling, waiting in line, I held my mother tightly and we were slowly moving forward. From a distance at the gate, we see several uniforms and whips cutting the air. Before us, the Gestapo officers are standing, our judges in smart clothes. They stand in a double row and make everyone run between them individually, driving him on with their whips. A short, guttural bark can be heard when they stop those running and tell them to join the party standing in the street. I remember like a nightmare that I ran through pulling my mother's hand. I look around; we are in a group of mostly young people. They are pulling aside the elderly and children. We are saved. We both have a slight nervous shock. We say nothing to each other, we only squeeze each other's hands

\footnotetext{
${ }^{6}$ It was the so-called kociot [lit. boiler] operation, meaning an ambush. Businesses in the ghetto were given fixed limits of employment, and workers were to obtain papers (or tin plaques with numbers) allowing them to remain in the ghetto. Everybody had to assembly in the vicinity of the streets of Smocza, Gęsia, Zamenhofa, Szczęśliwa, and Miła (hence the commonly used name of the operation - "the Miła Street ambush" [kocioł na Miłej]). Within a few days a great selection of the ghetto residents was carried out there, and as a result, about 50 thousand Jews were deported to Treblinka.
} 


\section{Materials}

and some nervous chills shake us. Next to us, people go through the same experience, or cry quietly after their loved ones who have gone to die. It is all over. Here comes the army that was searching private apartments and they march off, leading more than half of the people taken away. I doubt there is ever a pen capable of describing exactly what happened later. The terrible screaming and crying, wailing after those loved ones. Unfortunately, nothing could be done. To calm everyone naive fake information was given that someone had gone to intervene on behalf of those people. After a couple of hours, people began to calm down. For a long time one could still hear their cries through the wide-open windows in the warm night. Slowly, people began to calm down. One can become used to anything. Life became a little calmer, but not for long. We learned that in other workshops the same thing was done. Life was very hard. Some food supply was started and we continued with our lives. There was nothing to sell and nowhere to sell. We ate a few times a week. In such a state I crept outside the workshop, which was guarded. I got out into the empty streets and I started to check empty homes and loot, looking for food. The streets were full of patrols, they fired at me a couple of times, every time I managed to escape and hide. I searched several houses. I was really scared, as in one of the emptied and silent apartments I nearly met plundering Ukrainians. Elsewhere with the Germans. From one such raid I brought a pack of honey and some moldy bread crusts. The second time, clothes and some cans. I moved the coat and clothes at night to Miła Street, there were some boys who went to the other side to work. I received 150 zlotys for it. Then, there were two loaves of bread. I was coming home with another one. We were running from gate to gate, listening if someone was coming or driving. Suddenly we heard an engine. The nearest gate was 20 meters away. Before we were able to hide, a blast from a machine gun knocked my companion down. I just looked back and I went on. Later my mother would not allow me to go anymore. If someone went out into the city, they generally never returned. My mother could not bear waiting for me. I also decided never to be parted from my mother. If we were to die, we would die together. I would not leave my mother alone. She would not die lonely. Until the last moment we would be together. Unfortunately, that was only my wishful thinking. One night, I woke up in the dark. The apartment was inhabited by 31 people. Movement, people are terrified, running back and forth. They are packing. No one knows exactly what is happening. In the end, we learned that we must all march out. There is no information where to, but everyone understands and knows. In the morning, after several hours of despair and goodbyes, we all set out together. The mood is stifling. People who know they are going to die. The Jewish police, upset, are trying to order us about. Looting of stores starts. I get a little packet of honey and marmalade. [crossed out: I have some bread. Recently I have started to trade bread. But when I took it up, the market was declining. A couple of loaves I had bought I had to use myself because I could not even get the price I paid. Because of this I still had some bread]. We find out more details. There are notices in the city that 
on 7 September it seems the entire population that remained in the district is to be moved to an area within several streets. The "pilgrimage" through the streets looking like a battlefield was terrible. Rags, broken furniture, quilts, and broken glass littered the streets. Glass panes shattered in all the shops. And the beautiful September sun only shone in the broken pieces of glass and lit up the terrible street, along which the convicts walked. Each workshop took up a few streets. And tired people, in thick clothes, with heavy bundles with which they never parted, came into the street and houses standing along it, packed densely, man by man. The sun was shining, beautiful and bright. A beautiful autumn day. But we did not see that. People suffer from horrible hunger. Somewhere, someone found a box of tomatoes. It was grabbed in a moment. In the evening we sleep somewhere in the hallway next to the stairs. Man next to man. I hear at night how people relieve themselves next to me. But I do not have the energy to protest. At night, mother has another attack. There is nothing I can do. Mother collapses in pain, her fingers scratching the stinking floor in the hallway. Strangers scream for silence. I sit with my mother, holding her hand and stare at the beloved features in the dark. A horrible mask of pain with bloody bitten lips drives me mad. I dig my fingers into my hair until it hurts and I curse God if he exists and sees it all. The next day, mother's pain does not cease. I am almost unconscious because of helplessness, I do not even see the people around me. I only remember that it was raining outside that day. An autumn day and I was sitting with my mother. Even now, writing this, I feel that my heart is heavy. I am not surprised that I already have some grey hair. At night, we fell into a light interrupted sleep, full of nightmares. Suddenly I feel some movement next to me. People are going somewhere. I get up to see. Behind the house there are Ukrainians, who surround us. Near them, under a fence, there is something white, a cart or something, and a couple of people are sneaking up to it. A terrible struggle for bread found in the cart ensues. They fight in silence. One takes the bread from the other and more and more people arrive. No one wonders why it was here. To this day I only guess that it was planted. Suddenly, a loud rattle of a machine gun. People next to me start moaning and fall. We withdraw slowly. The fire ceased. And then all those surviving lunge forth again. No one hesitates. Fire, once again. Again, some are dead; happy, with a few crumbs under my shirt and a broken quarter of bread in my hand, I go back to my mother.

Next day we all line up. We are certain that everyone is going to the Gdański station. It turns out that three thousand people from our workshop can stay. The management of the workshop gives out certificates to supposedly the best workers; in fact they are their friends and relatives. They will return, and the rest will stay and wait for transport. My mother and I have already lost hope. It is a miracle that we have come this far. I see women taking everything out of their backpacks and putting their children inside. At checkpoint the children are taken from their mothers. We stand at the beginning of a procession of ten thousand people. We have no certificates. We are close to the checkpoint when we 
hear that for now they are only taking children and the elderly. It gives me some comfort and I whisper to my mother that if we are to be saved, it is only together; I will not leave her alone. Somewhere next to us children are crying, packed into backpacks, crushed, and suffocating, but they calm down before the checkpoint. There are four more fives to go, three, two. In front of us, some frail old man is pulled out with his wife, they are holding tightly together. I have no idea how they have managed to come this far. We stand in front of a tall Gestapo officer. His eyes move from face to face, and then, with a nod of his whip, we are pardoned. Then stop. He directs us to a large group of people. They count 3,000 and stop. Others, whether they have certificates or not, are lost. I hold my mother's hand and we march on. Next to us a child in a pram is crying piteously. The mother does not know where we are going and she is afraid to take him out. But the child is crying louder and louder. The mother discards the pram and pulls a 7-year-old boy out of it. The mother drags him on the ground because the boy's legs are numb after five hours in the pram. We're in front of the workshop, waiting for something, no one knows what. Orphans mourn in silence. We learn that we have to clean up the bodies of people murdered in the apartments. Again, they are giving out certificates, and again, I do not get any. Then everyone goes to the houses. We shall get certificates later. Meanwhile, there are 150 of us and we stay in the square in front of the workshop. In the evening, they tell us to go to a separate apartment. One piled on top of another. Apparently, one cannot be in the house without a certificate. I turn to Szymon Kac, head of the workshop. My mother is in pain again. In a trembling voice, I ask him for a release tomorrow, I will come myself. He must have sensed what I was going through, because he consented. Mother feels better. The next day, it's already evening when they tell everyone to move to the square, and proclaim that anyone who does not have a certificate is to report at the square. This way, all the survivors will be legalized. Along with the others; we go to the square. Without anything, we shall be coming back soon. On the square, we are suddenly surrounded by escort and when Kac wants to pull his friends out, the realization dawns on us that after all those tribulations, we are lost on the last day of the operation. Along with everyone else, I throw myself at him and, beaten with a baton on the head by a police officer, I shout his name. He looked at me, thought for a moment, and pulled me out. I yanked my mother and so I got out of the escort with her. There were twelve of us, and the rest were gone. Another one broke away from the group and started running towards us. The SS officer fires and the figure falls. I went home. I was legalized. But I could not enjoy it. Mother had another attack. I sat next to her for 24 hours. I cannot describe those hours of torment. Hard days came again. It was already after the deportation, but hunger was perhaps even worse than that. I was already selling things from myself, that my own shirt, shoes, and coat - I had almost nothing left and there was nothing to eat. There were already Polish policemen at the walls of the ghetto and so prices started to fall and food appeared on the market, but then I had no money to buy it. I began to dream about a poison. I did not want 
to suffer like that any longer. In addition, mother's attacks came more and more frequently. I could not sleep at night thinking what would happen later. The Germans are at Stalingrad, the war goes on and on, and I can vegetate like that for no more than a month. I actually had no idea how to survive that month. In addition, the winter is coming. It is October, it is getting colder. And then I started to mentally prepare myself so that I knew that would not survive the war. No matter how I die, better from a bullet than from hunger. And then I started my life as $\mathrm{J}^{7}$. I risked my life. I went to the other side. Risking my life, I brought goods to the ghetto to a friend, who invested money in me. I also took goods from him. He made a profit and so did I, and most importantly I could feed my mother. Every week I got through the wall for inventory and how happy I was when I saw my mother feeling better. I tried to calm her down and tell her that there was no danger in my work. She pretended to believe me and I saw how she was afraid for me. Three times I have been shot at by the wall. Gendarmes who replaced the Polish police were standing every 30-40 meters. One had to wait until they were distracted. But I was happy. I was not afraid at all. I was not afraid of death at all. I just prepared myself mentally that I must die. It is quite obvious that I shall not survive the war. The Germans were at Stalingrad and there was no hope that the war would end soon. Under such conditions, without papers, constantly risking death, I knew I would be caught. If not today, then tomorrow, but it is impossible to keep doing it in a long run. So every time when there was danger a thought came that it was probably the end, but I was not afraid at all and I knew it was natural. So many great people have perished, important people who could do so much good for the world and humanity, so when I die the sky will not fall. Actually, it is just a miracle that I am still alive so far.

A few times they checked my paper at the wall. I gambled everything on one card. I bribed the policeman. Working by the wall, where there were patrols all the time, death lurked at every turn. Unfortunately, every day there were the victims at the wall. Still, each day smuggling continued in the ghetto in full swing. "Blue" policemen could always be bribed. Later, we did not bribe gendarmes. Earnings were higher, but the risk was greater still. We often looked at them and, when they were distracted or turned away, we would throw the package over. I earned well. I denied myself nothing. I lived as a desperado. And of course, I sent to my mother the best of whatever I had. I only stayed away from women, firstly, because I was too exhausted and numb, and I only began to recover. And secondly, I was afraid I might catch some disease and through my own fault shorten my life, because there was no way to get treatment from Jewish doctors and I would be unable to work. I was so happy to be alive and eating to my heart's content, and to be able to provide the same for my mother. Just as now, after leaving the camp, I still cannot believe that is real, I think it is a dream. And then I was hanging on, not believing myself.

\footnotetext{
${ }^{7}$ J., as in "Jan" - a reference to the change of name and transformation into an "Aryan."
} 
Today, my happiness is clouded by the absence of my mother and my father, the latter whom I treated unfairly failing to mention him even once. My father had been in Sosnowiec since 1940. He fared no better than us. Before deportation, we lost contact with him. During the deportation, we thought little about father. We did not know that the operation against the Jews was carried out everywhere. We thought we were the only ones to perish. Later, I mourned both my father and my mother.

Translated by Katarzyna Gucio

\begin{abstract}
Abtract
Jan Górnicki's notes, written in May 1945, concern the days of the great deportation action in the Warsaw ghetto in July 1042. He was a young boy then, living with his mother and trying to earn some money riding a rickshaw. He describes the deteriorating conditions of the life in the ghetto and people in quest of any means to survive. In the end he presents dramatic scenes from Umschlagplatz, where the ghetto inhabitants were gathered for deportation.
\end{abstract}

\title{
Key words
}

the Warsaw ghetto, hunger, hapers, rickshaw, Umschlagplatz, the Jewish police, the great deportation action 